\title{
Analisis Kecepatan Angin Pesisir Pantai Monpera Sebagai Sumber Energi Terbarukan Kota Balikpapan
}

\author{
Adhe Yusphie Panca Tentra Sandika ${ }^{1 *}$, David Christover ${ }^{2}$, Mohammad Saiful Rozikin ${ }^{3}$, Budiani Fitria \\ Endrawati $^{4}$ \\ 1,2,3,4 Institut Teknologi Kalimantan, Karang Joang, kota Balikpapan \\ *E-mail: tetraskeith01@gmail.com
}

\begin{abstract}
Balikpapan as one of the cities in East Kalimantan with unique characteristic region of topographic condition consisting coastal area with hilly land that wind potential can be utilized. Based on data from BAPPEDA Balikpapan city explained that the topography of Balikpapan is almost entirely hilly (85\%), and the height of area from sea level ranges is 0-80 meters. Characteristics of the region, the height of the area from the sea surface is one of the factors that affected the movement of the existing airflow thus affecting the wind speed generated in coastal city Balikpapan. Based on the phenomenon, became an object of our research to knowing how big the potential of coastal breeze MONPERA to becoming a source of renewable energy. This research uses media tools to supported in taking research data that is horizontal wind turbine DC 12 / $24 \mathrm{~V} 400 \mathrm{~W}$ so that will get results of data consists of wind speed, maximum power, real power and total power obtained which the results is the highest wind speed equal to 11,15 knots $(5.66 \mathrm{~m} / \mathrm{s})$, maximum power is 74,129 Watt, real power is 39,99 Watt, total power is 125,092 Watt and electrical power is 27,18 Watt.
\end{abstract}

Keywords: Balikpapan, Potential, Power, Speed, Wind

\begin{abstract}
Abstrak
Balikpapan sebagai salah satu kota di Kalimantan Timur, merupakan kota dengan karakteristik wilayah yang cukup unik dengan kondisi topografi wilayah yang terdiri dari daerah pesisir dengan daratan yang berbukit hingga potensi angin yang dapat dimanfaatkan. Berdasarkan data Bappeda kota Balikpapan menjelaskan bahwa topografi Balikpapan yang hampir seluruhnya berbukit (85\%), serta ketinggian wilayah kota Balikpapan dari permukaan air laut berkisar 0-80 meter. Karakteristik wilayah, ketinggian daerah dari permukaan laut merupakan salah satu faktor yang berpengaruh terhadap gerak aliran udara yang ada sehingga mempengaruhi kecepatan angin yang dihasilkan di pesisir kota Balikpapan. Berdasarkan fenomena tersebut, hal ini menjadi sebuah objek penelitian kami dalam mengetahui seberapa besar potensi kecepatan angin di pesisir pantai MONPERA kota Balikpapan untuk menjadi sumber energi terbarukan. Penelitian ini menggunakan media alat yang menunjang dalam pengambilan data penelitian yaitu berupa turbin angin horizontal DC 12/24V $400 \mathrm{~W}$ sehingga akan didapatkan hasil data berupa kecepatan angin, daya maksimum, daya nyata dan daya total yang diperoleh pada daerah tersebut yaitu kecepatan angin tertinggi sebesar $11.15 \mathrm{knot}(5,66 \mathrm{~m} / \mathrm{s})$, daya maksimum sebesar 74,129 Watt, daya nyata sebesar 39,99 Watt, daya total sebesar 125,092 Watt dan daya output elektrik sebesar 27,18 Watt.
\end{abstract}

Kata kunci: Angin, Balikpapan, Daya, Kecepatan, Potensi

\section{PENDAHULUAN}

Berdasarkan data Bappeda kota Balikpapan [1] bahwa luas wilayah kelas lereng di kota Balikpapan adalah 0-2\% seluas $6.976 \mathrm{Ha}, 2-$ $15 \%$ seluas $5.709 \mathrm{Ha}, 15-40 \%$ seluas $12.394 \mathrm{Ha}$, serta $>40 \%$ seluas 18.171 Ha.Data tersebut menunjukkan bahwa sebagian besarwilayah Kota Balikpapan mempunyai kelas lereng $>40 \%$ yakni seluas 18.171 Ha. Kemiringan ini dampak pada topografi Balikpapan yang hampir seluruhnya berbukit $(85 \%)$, terutama dibagian utara wilayah kota, serta ketinggian wilayah kota Balikpapan dari 
permukaan air laut berkisar 0-80 meter.Karakteristik wilayah serta ketinggian daerah dari permukaan laut Kota Balikpapan merupakan salah satu faktor yang berpengaruh pada unsur-unsur curah hujan dan tinggi rendahnya suhu yang ada, sehingga mempengaruhi cuaca serta iklim kota Balikpapan yang tidak menentu. Akibat hal tersebut maka kecepatan angin yang ada di Kota Balikpapan termasuk labil dan memiliki potensi yang tidak menentu untuk digunakan sebagai renewable energy (energi terbarukan) sehingga diperlukan adanya penelitian lebih lanjut guna mengetahui hal tersebut [2].

\section{METODOLOGI}

Metode penelitian dapat digambarkan pada FlowChart, dapat dilihat pada gambar 1 sebagai berikut:

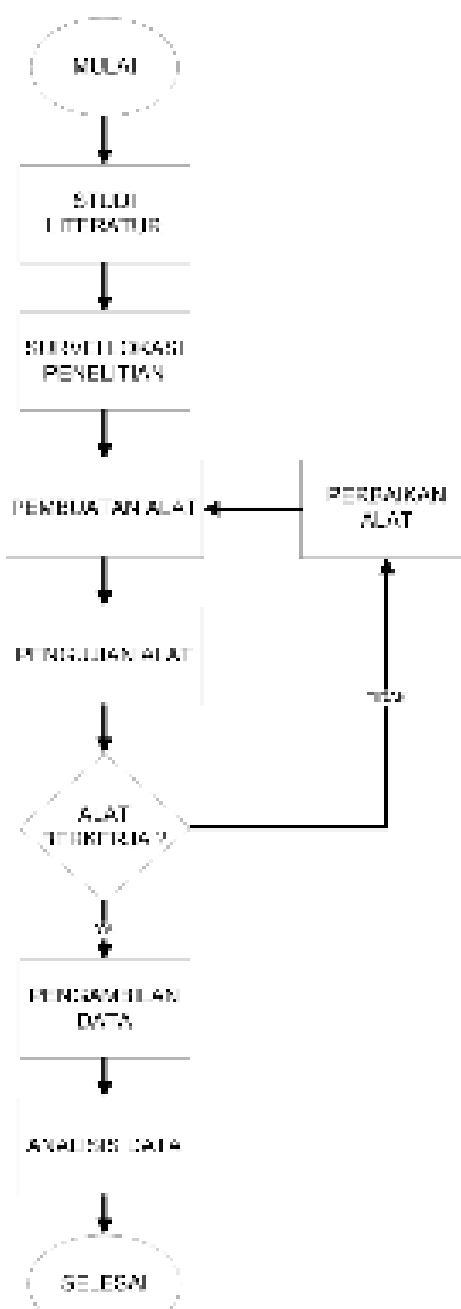

Gambar 1. Flowchart Metode Penelitian

\section{Pengumpulan Informasi}

Metode yang digunakan dalam studi literatur adalah dengan mencari sumber-sumber data dari buku dan jurnal yang berkaitan dalam menunjang pembuatan proposal penelitian tersebut. Instrumen alat kami adalah dengan menggunakan turbin angin (wind turbine) 400W 12/24V, inverter, sensor dan buku-buku yang berkaitan dengan tema kegiatan penelitian [3].

\section{Survei Lapangan}

Dalam penelitian harus dilakukan pengamatan lokasi yang akan dituju yaitu pesisir pantai MONPERA terkait dengan perancangan tepat guna di pesisir pantai yang mempunyai potensi kecepatan angin yang tinggi dan pemakaiannya lebih efisien. Dalam hal ini masalah yang ada adalah kecepatan angin di kota Balikpapan yang tidak menentu, serta untuk mengetahui apakah kecepatan angin kota Balikpapan memiliki potensi sebagai sumber energi terbarukan atau tidak [2].

\section{Pembuatan Media Alat Penelitian}

Perakitan alat ini bertujuan untuk mendapatkan mekanisme dan fungsi yang optimal dengan memperhatikan data yang telah didapat berdasarkan hasil observasi. Berikut merupakan komponen yang digunakan dalam penelitian tersebut adalah:

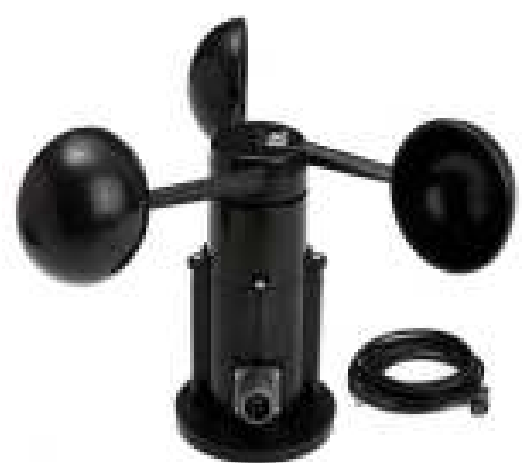

Gambar 2. Sensor Anemometer Vertikal

Sensor Anemometer Vertikal sebagai alat untuk mengukur kecepatan angin dari segala arah.

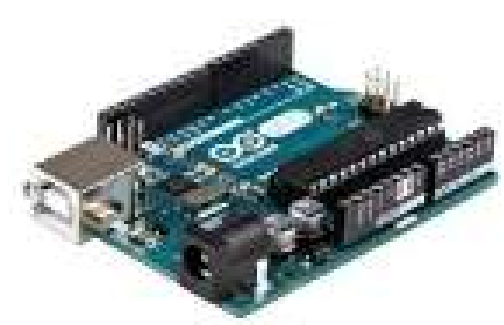

Gambar 3. Arduino Uno 
Arduino Uno sebagai mikrokontroler yang mengatur seluruh fungsi kerja seluruh sensor yang digunakan.

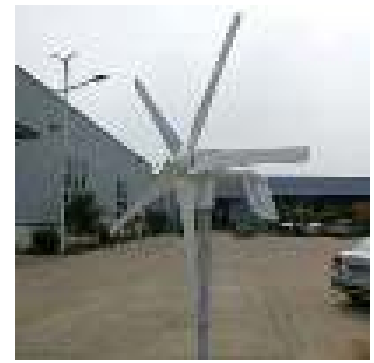

Gambar 4. Turbin Angin

Turbin angin sebagai sumber pembangkit listrik dan alat utama mengukur daya.

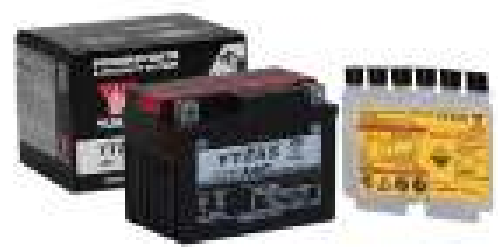

Gambar 5. Accu $12 v 3.5 \mathrm{~A}$

Aki $12 \mathrm{v} 3.5$ A sebagai baterai penyimpan daya yang dihasilkan oleh turbin angin.

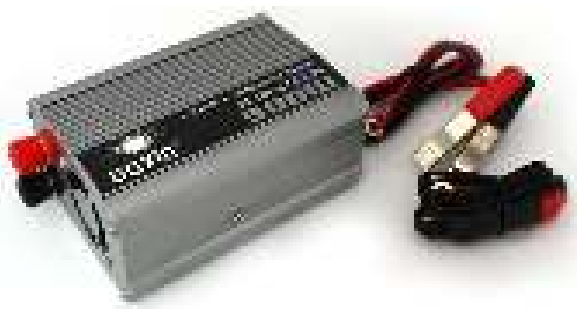

Gambar 6. Inverter DC to $A C 300 W$

Inverter berfungsi untuk mengubah arus DC pada aki menjadi arus AC.

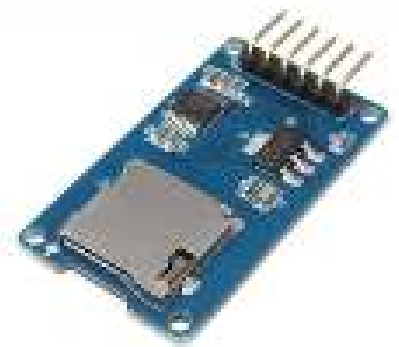

Gambar 7. Micro SD Module
Micro SD Module berfungsi sebagai media penyimpan data di dalam SD Card atau kartu memori.

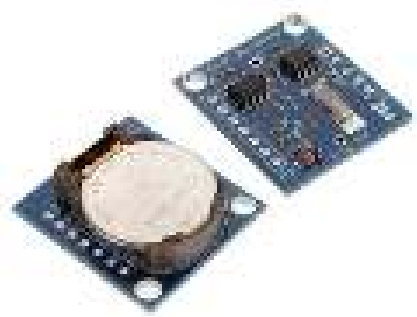

Gambar 8.RTC(Real Time Clock)

RTC sebagai pengatur waktu secara Real Time.

Dari komponen tersebut kemudian disatukan hingga membentuk media akhir untuk penelitian adalah sebagai berikut:

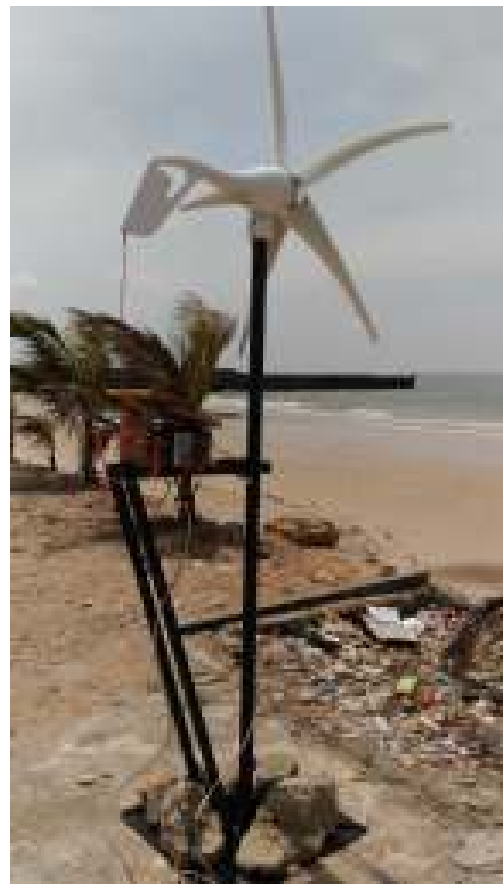

Gambar 9. Rangkaian Alat Setelah Disatukan

Proses kerja alat ini adalah dengan memberikan suplai listrik melalui turbin angin untuk disimpan ke dalam baterai/accu dan dilengkapi Inverter $D C$ to $A C 300 \mathrm{~W}$ digunakan untuk menghidupkan mikrokontroler Arduino Uno dan sensor. Sensor yang berupa anemometer vertikal dihidupkan untuk membaca data kecepatan angin melalui mikrokontroler untuk disimpan ke Micro SD Module yang diintegrasikan dengan RTC Module sebagai pemberi tanda berupa waktu pengambilan setiap data. 


\section{HASIL DAN PEMBAHASAN}

\section{Efisiensi Turbin Angin}

Efisiensi pada turbin angin adalah perbandingan antara energi kinetik yang diserap oleh turbin angin terhadap energi kinetik angin yang tersedia dan dapat diperhitungkan sebagai berikut:

$$
\begin{aligned}
\mathrm{Cp} & =\frac{\text { Daya maksimum Turbine }}{\frac{1}{2} * \rho * \mathrm{~A} * \mathrm{v}^{3}} 100 \% \\
\mathrm{Cp} & =\frac{400}{\frac{1}{2} * 1,22 * 1,13097 *(5,66)^{3}} 100 \% \\
\mathrm{Cp} & =31,97 \%
\end{aligned}
$$

Keterangan:

$\mathrm{Cp}=$ Efisiensi Turbin

$\rho=$ Densitas udara $\left(\mathrm{Kg} / \mathrm{m}^{3}\right)$

$\mathrm{A}=$ Luas Penampang $\left(\mathrm{m}^{2}\right)$

$\mathrm{v}=$ Kecepatan Angin (m/s)

\section{Energi Kinetik}

Dikarenakan angin adalah udara yang bergerak maka udara mempunyai massa sehingga energi yang ditimbulkannya dapat dihitung sebagai berikut:

$$
\begin{aligned}
& \mathrm{Ek}=0,5 * \mathrm{M} * \mathrm{v}^{2} \\
& \mathrm{Ek}=0,5 * 15 *(5,66)^{2} \\
& \mathrm{Ek}=240,267 \mathrm{~J} \\
& \text { Keterangan: } \\
& \mathrm{M}=\text { massa }(\mathrm{kg})
\end{aligned}
$$

\section{Daya Total Mekanis}

Dayatotal aliran angin adalah sebanding dengan tenagakinetik aliran udara yang dapat diperhitungkan sebagai berikut:

$$
\begin{aligned}
& \text { Ptot }=\frac{1}{2 \mathrm{Gc}} * \rho * \mathrm{~A} * \mathrm{v}^{3} \\
& \text { Ptot }=\frac{1}{2 * 1} * 1,22 * 1,13097 *(5,66)^{3} \\
& \text { Ptot }=125,092 \text { watt }
\end{aligned}
$$

Keterangan:

$\mathrm{Gc}=$ Faktor Konversi

\section{Daya Maksimum Mekanis}

Daya maksimum angin yang dapat diserapoleh sudu rotor dapat diperhitungkan sebagai berikut:

$$
\begin{aligned}
\operatorname{Pmax} & =\frac{8}{27} * \rho * \mathrm{~A} \\
* \mathrm{v}^{3} & \\
\operatorname{Pmax}= & \frac{8}{27} * 1,22 * 1,13097 *(5,66)^{3} \\
\operatorname{Pmax}= & 74,129 \text { watt }
\end{aligned}
$$

\section{Daya Nyata Mekanis}

Daya nyata adalah daya yang dapat dimanfaatkan oleh turbin untuk dijadikan sebagai energi baru yang dapat diperhitungkan sebagai berikut:

$$
\begin{aligned}
& P=C p * \text { Ptot } \\
& P=31,97 \% * 125,092 \\
& P=39,99 \text { watt }
\end{aligned}
$$

\section{Kecepatan Sudut}

Selanjutnya adalah menemukan nilai kecepatan sudut turbin dengan asumsi kecepatan putar sebesar 500 rpm adalah sebagai berikut:

$$
\begin{aligned}
\omega & =\frac{\pi * \mathrm{n}}{30} \\
\omega & =\frac{\pi * 500 \mathrm{rpm}}{30} \\
\omega & =52,36 \mathrm{rad} / \mathrm{s}
\end{aligned}
$$

\section{Torsi}

Semua benda yang berputar selalu terdapat torsi, yaitu gaya yang menyebabkansebuahtetapdapatberputarpad akecepatanputarnya. Setelah menemukan nilai kecepatan sudut, besarnyatorsi dapat diperhitungkandalampersamaan sebagai berikut: 


$$
\begin{aligned}
\tau & =\frac{\pi * \mathrm{D} * \text { Ptot }}{\omega} \\
\tau & =\frac{\pi * 1,2 * 125,092}{52,36} \\
\tau & =9,007 \mathrm{Nm}
\end{aligned}
$$

Keterangan:

$\mathrm{D}=$ Diameter $(\mathrm{m})$

\section{Tip Speed-Ratio}

Tip - Speed Ratio (TSR) adalah perbandingan kecepatan angin dengan kecepatan sudu. Lalu untuk kecepatan angin nominal tertentu, TSR akan berpengaruh pada kecepatan putar rotor. TSR dapat diperhitungkan sebagai berikut:

$$
\begin{aligned}
& \lambda=\frac{\pi * \mathrm{D} * \mathrm{n}}{60 \mathrm{v}} \\
& \lambda=\frac{\pi * 1,2 * 771}{60 * 5,66} \\
& \lambda=8,56
\end{aligned}
$$

Keterangan:

$\mathrm{n}=$ Kecepatan Putar (rpm)

\section{Tegangan yang Dibangkitkan}

Berikutnya adalah menemukan tegangan yang dibangkitkandengan jumlah lilitan per kumparan sebanyak 50 lilitan, frekuensi sebesar 50 $\mathrm{Hz}$, nilai kumparan stator sebanyak 6 buah, jumlah fase sebanyak 1 fase dan nilai fluksnya neodydmium $\mathrm{N} 50$ sebesar $1,45 \mathrm{~Wb} / \mathrm{m}^{2}$ dengan menggunakan perhitungan sebagai berikut:

$$
\begin{aligned}
& E_{S}=2 \pi * f * N * \emptyset * \frac{N_{S}}{N_{p h}} \\
& E_{S}=2 \pi * 50 * 50 *(1,45 * 0,0004) * \frac{6}{1} \\
& E_{S}=53,72 \text { Volt }
\end{aligned}
$$

Keterangan:

$\mathrm{E}_{\mathrm{S}} \quad=$ Tegangan yang dibangkitkan (Volt)

$\mathrm{f} \quad=$ Frekuensi $(\mathrm{Hz})$

$\mathrm{N}=$ Jumlah lilitan per kumparan

$\emptyset=$ Nilai fluks neodydmium N50 $\left(\mathrm{Wb} / \mathrm{m}^{2}\right)$

$\mathrm{N}_{\mathrm{S}}=$ Nilai kumparan stator

$\mathrm{N}_{\mathrm{ph}}=$ Jumlah fase

\section{Daya Output Elektrik}

Setelah mendapatkan nilai dari kecepatan sudut dan torsi, maka berikutnya adalah menemukan nilai daya output dengan nilai arusnya sebesar 0,506 Ampere menggunakan perhitungan sebagai berikut:

$$
\begin{aligned}
& \text { Pout }=E_{S} * I \\
& \text { Pout }=53,72 * 0,506 \\
& \text { Pout }=27,18 \text { watt }
\end{aligned}
$$

Keterangan:

$\mathrm{I}=$ Arus (Ampere)

Kemudian, berdasarkan data yang ditampilkan pada gambar 10 tersebut memberikan penjelasan berupa tingkat kestabilan kecepatan angin selama 9 jam dimana kecepatan angin tersebut lebih seimbang dengan adanya peningkatan dan penurunan pada tiap 1 jam yang memiliki variabel tidak begitu jauh sehingga lebih konsisten. Hal ini sesuai dengan teori pada jurnal penelitian World Meteorological Organization Instruments And Observing Methods Report No.106 yang menyatakan bahwa hasil data dengan analisis yang akurat membutuhkan tingkat efisiensi dan tingkat konsistensi tertentu dimana jumlah variabel antar data tidak memiliki tingkat yang jauh dan dominan kecil perbedaannya agar memiliki hasil data yang sesuai [4].

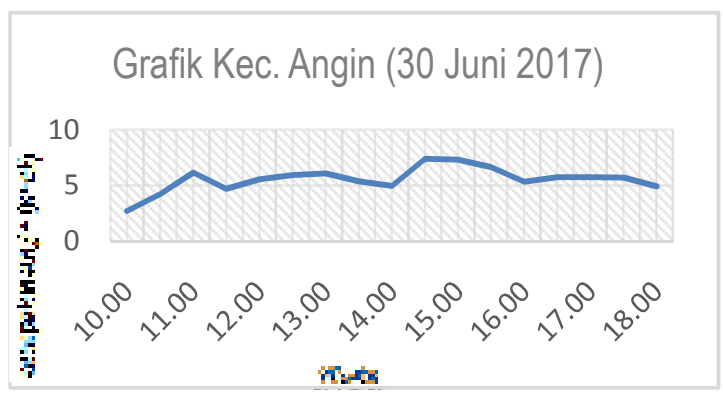

Gambar 10. Data kecepatan angin pada 30 Juni 2017

Data yang ditampilkan pada gambar 11 memberikan penjelasan dengan adanya perubahan signifikan dimana pada gambar tersebut menampilkan adanya tingkat penurunan kecepatan angin yang cenderung menurun dan memiliki tingkat kenaikan yang lebih sedikit perbandingannya namun memiliki variabel yang tidak begitu jauh dan dominan memiliki nilai perbedaan yang kecil. Tingkat dominan penurunan 
kecepatan angin dengan variabel terjauh hanya terjadi pada pukul 10:00 WITA hingga 11:00 WITA setempat sehingga analisis dari hasil data tersebut masih bisa diterima sesuai dengan teori jurnal penelitian World Meteorological Organization Instruments And Observing Methods Report No.106 [4].

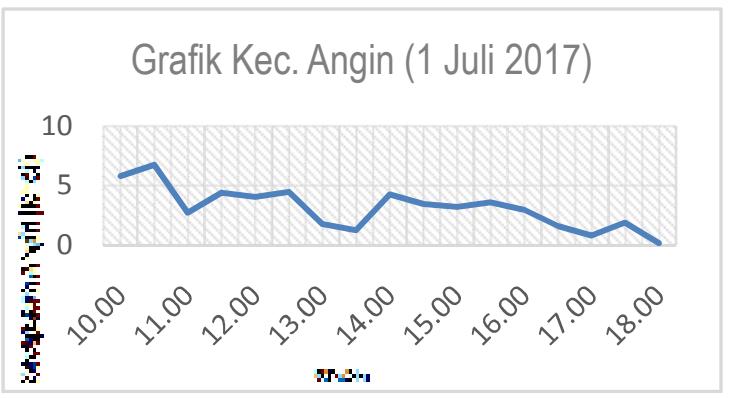

Gambar 11. Data kecepatan angin pada 1 Juli 2017

Data yang ditampilkan pada gambar 12 memberikan penjelasan yang menyatakan adanya tingkat penurunan signifikan pada pukul 10:00 WITA sampai dengan 11:00 WITA setempat yang kemudian pada jam-jam setelahnya kembali stabil dengan tingkat penurunan dan peningkatan yang seimbang dengan variabel nilai perbedaannya yang cenderung kecil. Jika dibandingkan dengan grafik pada gambar 11, hasil analisis data pada gambar 12 memiliki nilai yang lebih tinggi dan jauh lebih stabil dibandingkan dengan gambar 11 yang cenderung memiliki penurunan tingkat kecepatan angin hingga mendekati nilai nol. Dalam hal ini, perlu diketahui bahwa nilai nol yang didapatkan dalam penelitian tetap dianggap ada atau bernilai dikarenakan nilai variabel nol sangat berpengaruh dalam hasil analisis akhir data yang berupa kesimpulan.

Penjelasan ini juga secara tidak langsung telah didukung dengan berdasarkan teori pada jurnal penelitian milik World Meteorological Organization Instruments And Observing Methods Report No.106 dan Guide Meteorological Instruments And Methods Of Observation yang menyatakan bahwa tingkat error suatu data ditentukan saat data tersebut tidak dapat dibaca atau terbaca dari instrumen yang digunakan beserta metodenya, yang hal ini memiliki perbedaan arti jika data yang dimiliki bernilai nol [4] [5].

\section{Grafik Kec. Angin (2 Juli 2017)}

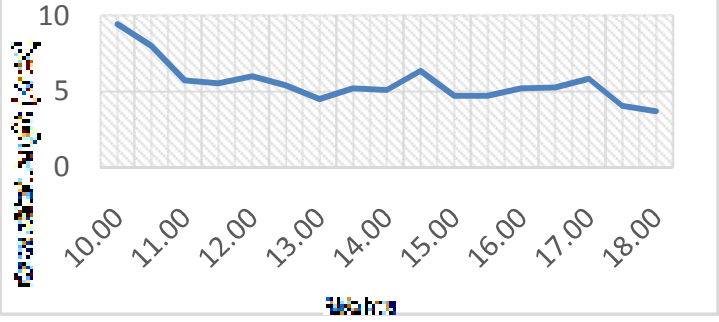

Gambar 12. Data kecepatan angin pada 2 Juli 2017

Data yang ditampilkan pada gambar 13 memberikan penjelasan berupa adanya penurunan tingkat kecepatan angin pada pukul 10:00 WITA sampai dengan 11:WITA dan mengalami peningkatan kecepatan angin yang sangat signifikan pada pukul 11:00 WITA hingga 11:25 WITA setempat, dimana pada jam-jam setelahnya mengalami kestabilan pada variabel data yang dihasilkan sehingga memiliki tingkat pemerataan pada peningkatan dan penurunan variabel yang cenderung seimbang.

Jika dibandingkan dengan grafik pada gambar 11, grafik pada gambar 13 memiliki peningkatan kecepatan angin jauh lebih tajam serta didahului oleh penurunan tingkat kecepatan angin yang tidak begitu signifikan dan sesuai dengan teori pada jurnal penelitian World Meteorological Organization Instruments And Observing Methods Report No.106 [4].

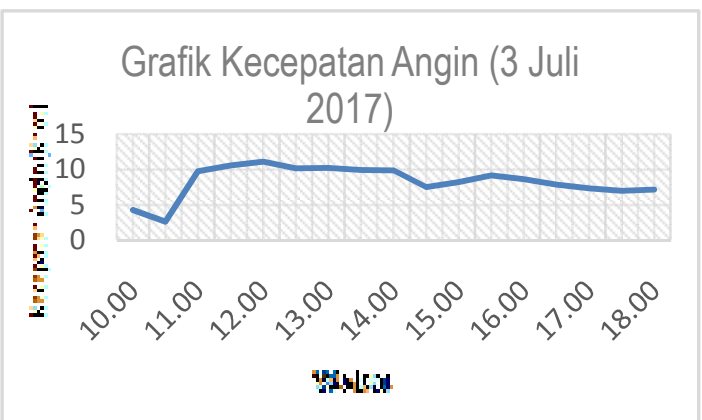

Gambar 13. Data kecepatan angin pada 2 Juli 2017

Kemudian, hasil data berupa kecepatan angin dapat dilihat pada tabel 1 sebagai berikut: 
Tabel 1. Hasil Data Kecepatan Angin

\begin{tabular}{llll}
\hline $\begin{array}{l}\text { Hari \& } \\
\text { Tanggal }\end{array}$ & \multicolumn{3}{l}{ Kecepatan Angin (knot) } \\
\cline { 2 - 4 } & Minimal & Maksimal & $\begin{array}{l}\text { Rata- } \\
\text { rata }\end{array}$ \\
\hline $\begin{array}{l}\text { Jumat, 30 } \\
\text { Juni 2017 }\end{array}$ & 1,9 & 8,2 & 5,55 \\
Sabtu, 1 & 0 & 8,4 & 3,14 \\
Juli 2017 & & & \\
Minggu, 2 & 3,3 & 10,8 & 5,58 \\
Juli 2017 & & & \\
Senin, 3 & 1,5 & 11,15 & 8,36 \\
Juli 2017 & & & \\
\hline
\end{tabular}

Berdasarkan pada data tabel 1 maka dapat diperhatikan bahwa pada hari Jum'at kecepatan angin 5,55 knot, lalu pada hari Sabtu kecepatan angin 3,14 knot, kemudian pada hari Minggu kecepatan angin 5,58 knot kondisi cerah dan pada hari Senin kecepatan angin 8,36 knot.

\section{KESIMPULAN}

Berdasarkan hasil kegiatan penelitian didapatkan berupa data kecepatan angin dan perhitungan daya yang diperoleh pada daerah tersebut, dapat diketahui bahwa kecepatan angin tertinggi yang dihasilkan adalah sebesar 11,15 knot atau $5,66 \mathrm{~m} / \mathrm{s}$ dengan perolehan daya maksimum mekanis sebesar 74,129 Watt, daya nyata mekanis sebesar 39,99 Watt, daya total mekanis sebesar 125,092 Watt dan daya output elektrik sebesar 27,18 Watt.

Hasil penelitian ini didapatkan dengan menggunakan turbin angin horizontal DC $12 / 24 \mathrm{~V}$ 400W dengan tinggi tiang penyangga sebesar 3 meter dan diameter sudu sebesar 1,2 meter sehingga masih adanya kemungkinan peningkatan terhadap energi listrik yang dihasilkan jika menggunakan turbin angin horizontal dengan ukuran yang lebih besar dan lebih tinggi serta pemasangan yang dilakukan secara merata di kota Balikpapan.

\section{SARAN}

Untuk penelitian selanjutnya, diperlukan setidaknya minimal 4 turbin angin jenis horizontal dengan spesifikasi yang sama agar didapatkan korelasi yang tepat mengenai kecepatan angin dengan listrik yang dihasilkan.

\section{UCAPAN TERIMA KASIH}

Penelitian tersebut tidak akan mendapatkan hasil yang sesuai jika tanpa adanya bantuan dari dosen pembimbing dan teman seperjuangan Institut Teknologi Kalimantan demi tujuan bersama yaitu penelitian dengan kebermanfaatan yang berkelanjutan.

\section{DAFTAR PUSTAKA}

[1] Badan Meteorologi, Klimatologi dan Geofisika. "Analisa Penyusun Kecepatan Angin Kota Balikpapan”. Balikpapan (2015).

[2] Badan Perencanaan Pembangunan Daerah. "Kajian Energi Terbarukan Di Kota Balikpapan”. Balikpapan (2015).

[3] Kalmikov, Alex. "Wind Power Fundamentals”. MIT University (2010).

[4] World Meteorological Organization. "World Meteorological Organization Instruments And Observing Methods Report No.106”. Geneva 2, Switzerland (2011).

[5] World Meteorological Organization. "Guide Meteorological Instruments And Methods Of Observation". Geneva 2, Switzerland (2011). 